\title{
Spatial analyses of threats to ecosystem service hotspots in Greater Durban, South Africa
}

\author{
Rashieda Davids ${ }^{\text {Corresp.. }}$ 1， Mathieu Rouget ${ }^{2}$, Richard Boon ${ }^{3,4}$, Debra Roberts ${ }^{4,5}$ \\ ${ }^{1}$ School of Agricultural, Earth and Environmental Sciences, University of KwaZulu-Natal, Pietermaritzburg, South Africa \\ 2 UMR PVBMT, CIRAD, Saint-Pierre, Reunion Island \\ 3 Environmental Planning and Climate Protection Department, eThekwini Municipality, Durban, South Africa \\ 4 School of Life Sciences, University of KwaZulu-Natal, Durban, KwaZulu-Natal, South Africa \\ 5 Sustainable and Resilient City Initiatives Unit, eThekwini Municipality, Durban, South Africa \\ Corresponding Author: Rashieda Davids \\ Email address: rashieda@enviroheart.co.za
}

Background. Population growth at all scales and rapid rates of urbanization, particularly in the global South, are placing increasing pressure on ecosystems and their ability to provide services essential for human well-being. The spatial consideration of threats to ecosystem services related to changes in land use is necessary in order to avoid undue impacts on society due to the loss or reduced supply of ecosystem services. This study assesses the potential threats of land use change from strategic and local development proposals to ecosystem services in the city of Durban.

Methods. We analysed the spatial relationship between five categories of ecosystem service hotspots (carbon storage, water yield, sediment retention, nutrient retention and flood attenuation) and urban land use change related to selected strategic planning proposals, development proposals and sandmining applications in Durban, South Africa (eThekwini Municipality) with a view to determining the consequences for progress towards a more sustainable development path in the city. We identified the potential levels of threat related to habitat destruction or transformation for the five categories of ecosystem services and a subset of 13 ecosystem service hotspots, using GIS spatial analysis tools.

Results. The results show that on average, should Durban's strategic development plans be realised, approximately $42 \%$ loss of ecosystem service hotspots is expected in the two municipal town-planning regions assessed. With respect to development applications between 2009 and 2012, approximately 36\% of all environmental impact assessments and $84 \%$ of sand mining applications occurred within ecosystem service hotspots within Durban.

Discussion. The findings highlight the tension between short-term development pressures and longerterm sustainability goals and confirm that current planning and development proposals pose a threat to ecosystems and their ability to deliver services that support human well-being in Durban. We suggest practical solutions to include ecosystem services into local government decision-making. 
1

2 Spatial Analysis of Threats to Ecosystem Service Hotspots in

3 Greater Durban, South Africa

5 Rashieda Davids ${ }^{1}$, Mathieu Rouget ${ }^{1,2}$, Richard Boon ${ }^{3,5}$, Debra Roberts ${ }^{4,5}$

61 School of Agricultural, Earth and Environmental Sciences, University of KwaZulu-Natal,

7 Pietermaritzburg, KwaZulu-Natal, South Africa

$8{ }^{2}$ CIRAD, UMR PVBMT, Saint-Pierre, Reunion Island

$9{ }^{3}$ Environmental Planning and Climate Protection Department, eThekwini Municipality, Durban,

10 KwaZulu-Natal, South Africa

$11{ }^{4}$ Sustainable and Resilient City Initiatives Unit, eThekwini Municipality, Durban, KwaZulu-Natal,

12 South Africa

$13{ }^{5}$ School of Life Sciences, University of KwaZulu-Natal, Durban, KwaZulu-Natal, South Africa

16 Corresponding Author:

17 Rashieda Davids ${ }^{1}$

18 Carbis Road, Pietermaritzburg, KwaZulu-Natal, 3201, South Africa

19 Email address: rashieda@enviroheart.co.za 
22 Abstract

23

24 Background. Population growth at all scales and rapid rates of urbanization, particularly in the global South, are placing increasing pressure on ecosystems and their ability to provide services essential for human well-being. The spatial consideration of threats to ecosystem services related to changes in land use is necessary in order to avoid undue impacts on society due to the loss or reduced supply of ecosystem services. This study assesses the potential threats of land use change from strategic and local development proposals to ecosystem services in the city of Durban.

Methods. We analysed the spatial relationship between five categories of ecosystem service hotspots (carbon storage, water yield, sediment retention, nutrient retention and flood attenuation) and urban land use change related to selected strategic planning proposals, development proposals and sand-mining applications in Durban, South Africa (eThekwini Municipality) with a view to determining the consequences for progress towards a more sustainable development path in the city. We identified the potential levels of threat related to habitat destruction or transformation for the five categories of ecosystem services and a subset of 13 ecosystem service hotspots, using GIS spatial analysis tools.

Results. The results show that on average, should Durban's strategic development plans be realised, approximately $42 \%$ loss of ecosystem service hotspots is expected in the two municipal town-planning regions assessed. With respect to development applications between 2009 and 2012, approximately $36 \%$ of all environmental impact assessments and $84 \%$ of sand mining applications occurred within ecosystem service hotspots within Durban.

43 Discussion. The findings highlight the tension between short-term development pressures and

44 longer-term sustainability goals and confirm that current planning and development proposals pose a threat to ecosystems and their ability to deliver services that support human well-being in Durban. We suggest practical solutions to include ecosystem services into local government decision47 making.

\section{Introduction}

51 Population growth at all scales and rapid rates of urbanization, particularly in the global South, are 
53 well-being (Steffen et al., 2015; United Nations, Department of Economic and Social Affairs (UN 54 DESA, 2015). Ecosystem services are the life sustaining benefits that humans derive from natural ecosystems (MEA, 2005), more recently referred to as 'nature's contributions to people (NCP),' which includes positive and negative contributions of nature to human quality of life (Diaz et al., 2018). Ecosystem services include regulating services (or regulation NCP) such as climate, water, air, hazard and disease regulation; provisioning services (or material NCP) such as healthy food supply, materials and medicines and cultural services (or non-material NCP) including education, inspiration, recreation, physical and psychological experiences (Costanza et al., 1997; Daily, 1997; MEA, 2005; TEEB, 2011; Diaz et al., 2018).

Anthropogenic environmental pressures including the conversion of natural ecosystems into urban areas has contributed impacts on global biodiversity hotspots such as species decline (Rockström et al., 2009; Seto et al., 2012), environmental degradation and climate change (Steffen et al., 2015). The negative consequences for human well-being due to impacts on ecosystems and ecosystems services (Larigauderie et al., 2012; MEA, 2005; McGranahan et al., 2005) will be compounded by risks associated with often abrupt, irreversible and non-linear ecosystem changes in response to disturbance regimes (Rockström \& Karlberg, 2010). Increasing populations in cities also mean greater demands for the life supporting ecosystem services provided by natural systems. In cities of the global South, these demands are exacerbated by poverty and direct dependence on ecosystem services for livelihoods and well-being (Shackleton \& Shackleton, 2004; Stoian, 2005; Davenport et al., 2012).

Despite their critical importance to human welfare, a consideration of ecosystem services is insufficiently integrated into landscape planning and management processes and decision making (Daily et al., 2009; de Groot et al., 2010; Nemec \& Raudsepp-Hearne, 2013). The neglect of ecosystem services in decision making can be attributed to the complexity of the ecosystem processes involved, including that services are often produced at some distance from urban beneficiaries (Baro et al., 2016); they rarely conform to property or administrative boundaries; public agencies find it difficult to manage and regulate them (McGranahan et al., 2005) and the fact that those most affected by the loss of ecosystem services are the urban poor, who are the least 
83 economically and politically influential (Shackleton \& Shackleton, 2004; Stoian, 2005; Davenport 84 et al., 2012).

85

86 The ecosystem services approach is, however, increasingly seen as a tool that allows for entry into 87 a broader set of social and political processes, with an expectation that this holistic approach could 88 be integrated at all governance levels and provide a basis for policy design (Diaz et al., 2015; 89 Primmer et al., 2015). New research is investigating various modes of governance, that consider 90 inputs and decision-making from a range of stakeholders, for all elements of ecosystem services, 91 from ecosystem structure, functions and services, to benefits and values (Primmer et al., 2015; 92 Potschin \& Haines-Young, 2011). This is most evident through the establishment of the 93 Intergovernmental Science-Policy Platform on Biodiversity and Ecosystem Services (IPBES) - the 94 intergovernmental body which assesses the state of biodiversity and of the ecosystem services it 95 provides to society.

97 The 2030 Agenda for Sustainable Development recognizes the need to reduce the impact of urban 98 development on life-supporting natural systems with the inclusion of Sustainable Development Goal (SDG) 11 focused on creating inclusive, safe, resilient and sustainable cities. (United Nations

100 Development Programme ,2016). Rockström \& Sukhdev (2017) highlight that natural capital and 101 ecosystem services are foundational in achieving the SDGs and their associated targets, given that 102 sustainable social and economic development is only possible if it occurs within the limits of the 103 environment. To this end, the targets associated with SDG 11 recognize the need for the protection 104 of natural heritage, the reduction of environmental impacts and for development planning that is 105 strengthened though positive economic, social and environmental links between urban, peri-urban 106 and rural areas (United Nations, 2015).

107

108 The city of Durban in South Africa has shown commitment to this understanding of sustainable 109 development (and more recently the SDGs) by virtue of its long history of biodiversity and 110 ecosystem services planning and management that culminated in the establishment of the Durban 111 Metropolitan Open Space System (D’MOSS) (McLean et al., 2016). Numerous threats to 112 biodiversity and the associated delivery of ecosystem services, however, still remain within the 113 city including habitat destruction and fragmentation - a minimum of 53\% of Durban's natural 
114 areas have already been transformed by human activities (eThekwini Municipality 2012a) - and

115 climate change (Roberts et al., 2012).

116

117 City wide strategic planning and localized development proposals are considered to be significant

118 drivers of land use change in Durban. Ecosystem services are extremely vulnerable to human

119 induced land use change impacts (Arunyawat \& Shrestha, 2016). The spatial consideration of

120 threats related to changes in land use with respect to ecosystem services is necessary in order to

121 help avoid inappropriate land uses that could reduce the supply of ecosystem services (Arunyawat

$122 \&$ Shrestha, 2016) and could greatly improve the selection of areas where the best conservation

123 outcomes could be achieved (Evans et al., 2011). Conservation planning is proposed as a tool for

124 responding to threats associated with land transformation, which in addition to habitat loss through

125 urbanisation and the associated expansion of infrastructure, includes extractive land uses

126 (agriculture, forestry, mining, grazing) and the spread of invasive alien species (Wilson et al., 127 2004).

In this study, we use Durban as a case study to assess potential levels of threat to five categories of ecosystem service hotspots (Davids et al., 2016), namely, carbon storage, water yield, flood attenuation, sediment retention and nutrient retention, related to habitat destruction or transformation, which may result from the implementation of strategic development proposals (as outlined in the Strategic Development Plans for the Outer west and North regions of the city), local development proposals (as identified through the associated environmental impact assessments) and sand mining proposals, using spatial analysis tools in ArcGIS.

\section{Methods}

\section{Study area}

142 Durban is administered by a local government authority known as eThekwini Municipality and is 143 situated in the province of KwaZulu-Natal, South Africa. In 2015 the municipal area of Durban 144 was approximately 229193 ha in extent (1.4\% of the province) with a population 3.55 million 
145 (Davids et al. 2016). Durban's coastline is $98 \mathrm{~km}$ long, and is dissected by the rivers of 18 major 146 water catchments and 16 estuaries. Furthermore, Durban is located within the Maputaland147 Pondoland-Albany global biodiversity hotspot, rated as such because of its high levels of plant 148 endemism and habitat loss (Mittermeier et al., 2004).

150 Durban contains urban, peri-urban and rural environments, with approximately two-thirds of the 151 municipal area being rural or semi-rural, where a large proportion of local inhabitants are indigent 152 and directly reliant on ecosystem services for basic needs (Roberts \& O’Donoghue, 2013; 153 Sutherland et al., 2014). Social challenges in Durban include high levels of poverty; many densely 154 populated informal settlements; unequal basic service delivery; high rates of urbanisation and dual 155 governance arrangements, whereby eThekwini Municipality jointly administers communal land in 156 the rural northwest and southwest areas of the municipality with the Ingonyama Trust Board (under

157 the jurisdiction of traditional councils) and provincial government (McLean et al., 2016; 158 Sutherland et al., 2014; Davids et al., 2016). These challenges have often meant that socio159 economic development priorities have taken preference over environmental and biodiversity 160 concerns (Roberts, 2008).

162 The Durban Metropolitan Open Space System (D’MOSS) is formally included in eThekwini 163 Municipality's hierarchy of spatial plans and policies, and serves as a legal instrument for 164 environmental protection through development and use restrictions. D'MOSS comprises natural areas of high biodiversity value within a series of interconnected open spaces, aimed at protecting globally significant biodiversity and the supply of ecosystem services (Roberts \& Donoghue, 2013;

167 Davids et al., 2016).

Overview of South African Spatial Planning Products Considered in this Study

In terms of the Constitution of the Republic of South Africa, 1996 (as amended), spatial planning

172 in South Africa is the responsibility of all three spheres of government, local, provincial and 173 national. The national Spatial Planning and Land-use Management Act (SPLUMA), 2013 (Act 174 No. 16 of 2013) provides the framework for all land use management and spatial planning 175 legislation in South Africa. This Act has numerous aims, including the regulation of planning 
176 procedures and decision making; addressing spatial imbalances that resulted from the apartheid 177 era and ensuring integration of sustainable development principles in land use planning and 178 regulatory tools.

179

180 In terms of SPLUMA, all spheres of government must prepare spatial plans, however, land use 181 management is the responsibility of municipalities, in participation with local traditional councils.

182 In Durban, the traditional councils administer communal lands totalling \pm 82266 ha (35.8\%)

183 (Davids et al., 2016). SPLUMA and the Municipal Systems Act, 2000 (Act No. 32 of 2000) require

184 that local municipalities develop land use management systems, including the implementation of 185 Integrated Development Plans (IDPs) and municipal spatial development frameworks (SDFs) and 186 associated land use guidelines. EThekwini Municipality's IDP (2012/2013) considered in this 187 study, was developed with the aim to address key strategic issues identified in the National Spatial 188 Vision and Provincial Growth and Development Strategy, including job creation; reversing the 189 effects of apartheid; access to quality of education, healthcare and social protection; and the 190 transition to a low carbon economy (eThekwini Municipality 2012). The IDP states that in order 191 to suitably manage development and minimise impacts on the natural environment and associated 192 ecosystem services, spatial planning must be enhanced and better aligned with the strategic 193 development plans of the Municipality (eThekwini Municipality, 2012).

\section{Data}

198

\section{Ecosystem service hotspots}

201 The classification, mapping and spatial prioritisation of ecosystem services has received 202 considerable attention (Egoh et al., 2008; Schröter and Remme, 2016; Cimon-Morin et al., 2013; 203 Schröter et al., 2017). Among other approaches, the delineation of 'ecosystem service hotspots' 204 has been used to spatially prioritise ecosystem services in conservation planning (Cimon-Morin et 
205

206

207

208

209

210

211

212

213

214

215

216

217

218

219

220

221

222

223

224

225

226

227

228

229

230

231

232

233

234

235

al., 2013). Ecosystem service hotspots either refer to areas of high ecosystem service values of one service, or areas with a combination of multiple services (Schröter and Remme, 2016).

Davids et al (2016) identified hotspots for 13 ecosystem services in Durban, grouped into five categories (Table 1). The 13 ecosystem services are: carbon storage, water yield (to dams), four sediment retention services (preventing sedimentation of dams, stormwater and sewer pipes and the harbour), three flood attenuation services (relevant to the population, private and public infrastructure) and four nutrient retention services (phosphorus and nitrogen relative to both dams and estuaries) (Table 1; Fig. 1). The original ecosystem service maps for these 13 services were commissioned by the municipality's Environmental Planning and Climate Protection Department in 2012 and were derived using the InVEST tool, developed by the Natural Capital Project (Tallis and Polaski, 2009). InVEST allows for priority ecosystem service areas to be identified based on a number of factors that either contribute, to or impact on selected ecosystem services (Glenday, 2012). ArcGIS 9.3 was used to estimate the ecosystem service provision based on biophysical properties, land over and location relative to downstream populations, property and infrastructure, along land surface and river channels flow paths (Glenday, 2012). These ecosystem services were linked to a standard $86.9 \mathrm{~m}$ resolution and scaled to values ranging from $0-100$, to indicate relative service provision compared to the maximum found in the study area.

Ecosystem service hotspots were defined by Davids et al. (2016) as the top $50 \%$ of ecosystem service provisioning areas (Fig. 1). These ecosystem service hotspots represent the provisioning areas of a particular service that had values greater than the median value (Davids et al. ,2016). The median value was used to reduce the importance of outliers present (Press et al., 1992) in the range of ecosystem service values and to avoid the exclusion of large areas providing good ecosystem services (Davids et al., 2016). Approximately 35\% of Durban was considered a hotspot for at least one of the 13 ecosystem services assessed (Fig. 2). Majority of the 13 ecosystem service hotspots identified by Davids et al., (2016) were found to be outside of environmental management areas and threatened by habitat transformation, rapid densification, invasive alien plant invasions and pollution, with only half of ecosystem service hotspots located within D'MOSS. The hotspot richness map (Fig. 2) was developed using overlay analysis, which merged the distributions of 13 ecosystem services provisioning maps into a raster grid (with a presence value of 1 for each map) 
236 to show the total number of ecosystem services produced in a particular location from a minimum

237 of 0 , to a maximum of 13 (Schröter and Remme, 2016, Davids et al., 2016).

238

239 Spatial Development Framework

240

241 The SDF forms part of a hierarchy of integrated plans that make up the Land Use Management 242 System currently being established to manage land use and development within Durban 243 (eThekwini Municipality, 2012). The intention of the SDF is to guide all decisions related to the 244 use, development and planning of land within Durban, providing a strategic framework that 245 spatially indicates how the implementation of the city's IDP should occur. The SDF is a five-year 246 plan, which is revised annually in line with the IDP. It provides strategic multi-sectoral planning 247 guidance relative to development priorities, transport planning, bulk infrastructure and 248 environmental directives, and acts as a guide to more detailed Local Area Plans, Functional Area 249 Plans, detailed Precinct Plans and Land Use Schemes. This study assesses the proposed changes 250 to land use that could occur through the implementation of the eThekwini Municipality Spatial 251 Development Plans (SDPs), against the 13 ecosystem service hotspots (Fig. 1).

252

253

The terminologies for land uses in the SDPs were not standardized and categories of land use were 254 grouped as follows: natural areas for environmental protection, nature-based recreation and 255 tourism, amenity, agricultural use and infrastructure.

256

257

\section{Spatial Planning Regions}

258

Durban's municipal area is divided into four major planning regions, namely, North, South, Central (including Inner West) and Outer West (Fig. 3). Within Durban, only 36\% of land is covered by town planning schemes and formally administered by the municipality, approximately $38 \%$ is communal land jointly administered by the traditional councils, and the municipality and $26 \%$ is peri-urban and jointly administered by local and provincial government (McLean et al., areas into town planning schemes (McLean et al., 2016). 
267 Under the SDF, four individual Spatial Development Plans (SDP) have been prepared and were 268 adopted in November 2009 and revised in November 2010 and 2011 (eThekwini Municipality 269 2012). Two SDPs (North and Outer West) were selected for use in this study, due to their 270 contrasting general land uses, that is one being more rural in the case of the Outer West SDP and 271 the other more urban in the case of the North SDP.

272

\section{Historical Development Applications}

274

275

276

277

278

279

280

281

282

283

284

285

286

287

288

289

290

291

292

293

294

295

296

Historical development applications assessed in this study include all environmental impact assessments and sand mining applications that were submitted to the Environmental Planning and Climate Protection Department of eThekwini Municipality, between 2009 and 2012. The applications were linked to a point file in GIS, thus the points used in the analyses are merely an indication of where transformation of land may be expected, in the event that applications were successful.

\section{Analyses}

We analysed potential transformation of land supplying ecosystem services for various ecosystem service-threat combinations, as shown in Tables 2 and 3. In addition to assessing individual services, we also grouped the 13 ecosystem services hotspots into the five main ecosystem service categories, namely, carbon storage, water yield, sediment retention, nutrient retention and flood attenuation (Table 1 and 2; Figs. 4 and 5) and analysed these services against potential transformation relative to strategic (Table 2) and local development threats (Table 3) in ArcGIS 10.1. For this analysis, we generated five ecosystem services maps (one for each category) by aggregating all ecosystem services maps per category based on the maximum value per cell.

To analyse the threat of transformation of land supplying ecosystem services related to the implementation of the SDPs in the North and Outer West Regions, we first grouped the planned land uses in each region in terms of their compatibility with ecosystem services. The compatibility of proposed land uses to the continued supply of ecosystem services was determined based on the 
297 potential of that land-use to maintain ecosystems in their natural or semi-natural state (rated as

298 'compatible') or where land is expected to be significantly modified (e.g. cultivated or urban), with

299 natural areas largely transformed (rated as 'incompatible'). Although we acknowledged that

300 significantly modified areas are able to produce some degree of ecosystem services (Colding et

301 al., 2006), for this study we assumed service values for these areas to be lost when transformed to

302 'incompatible' land uses (Reyers et al., 2009).

303

304 Compatible land uses include D'MOSS, environment, public open space, green corridor, amenity, 305 dam, tourism (Figs 4 and 5; Appendices 1- 4). D'MOSS is included within the municipal town 306 planning schemes as a controlled development layer (Roberts \& O'Donoghue, 2013) and 307 comprises protected areas, nature reserves and terrestrial, estuary and freshwater biodiversity 308 areas, and environmental approval is required prior to any development taking place within 309 designated D'MOSS areas, thus offering some form of protection from transformation (Davids et 310 al., 2016). These biodiversity areas have been shown to support ecosystem service production

311 (Davids et al., 2016; Chan et al., 2006; Egoh 2009; Turner et al., 2007; Singh, 2002).

312

313 Incompatible uses include land that will be transformed from natural or semi-natural states and 314 would result in reduced or lost productivity of biodiversity and associated the ecosystem services

315 (de Groot et al., 2010; McGranahan et al., 2005), include agriculture, equestrian, urban and rural 316 residential, rural cemetery, landfill, mixed use, town centre, business park, industry, extractive, 317 airport and tradeport (constituting the support zone to airport-related activities including 318 infrastructure, offices, warehouses and cargo terminal). We grouped agricultural land-use as being 319 not compatible with ecosystem services, based on the understanding that increasing productivity 320 generally results in a loss or decline in ecosystem services (Kareiva et al., 2007), whereby 321 agriculture may result in negative impacts on biodiversity though direct modifications (removal or 322 addition of biota: predators, pests and parasites of domestic species) and indirect modifications 323 (changes to biogeochemical cycles, and changes to hydrological cycles); and changes to the 324 habitats of native species (Baudron \& Giller, 2014). 
326 The percentage of ecosystem services provision areas that may be lost due to incompatible land-

327 uses was calculated based on the results of raster calculator analyses of each ecosystem service

328 hotspot with the various proposed land uses in the two SDP regions analysed.

329

330 Development and sand mining proposals pose potential impact on ecosystem services due to

331 biodiversity impacts in the form of vegetation clearing and the removal of life-supporting topsoil

332 (eThekwini Municipality, 2012a). To analyse the potential levels of threat to ecosystem services

333 linked to development proposals, the locations of all environmental impact assessment and sand-

334 mining applications were overlaid with each of the 13 ecosystem service hotspots, to assess the

335 proportion of applications that were planned to occur in these hotspots. These locations were also

336 overlaid with an ecosystem service hotspot richness map (Davids et al., 2016), to assess the

337 proportion of applications that were planned to occur within areas that supply a combination of

338 ecosystem services. The limitation here is that the positions alone do not provide a quantitative

339 assessment of the extent of potential transformation of ecosystem service hotspots. However, this

340 analysis provides an indication of the demand for transformation of natural areas providing

341 ecosystem services related to the volume of applications made in ecosystem hotspots.

\section{Results}

346

Spatial Development Plans: Outer West and North Planning Regions in relation to priority areas for the five categories of ecosystem services

The proposed implementation of the SDPs will affect ecosystem service provision in both regions. On average, $60 \%$ and $47 \%$ of ecosystem service hotspot areas in the North and Outer West designated to remain natural, such as environment, D'MOSS, public open space, green corridor and amenity (Table 2; Fig. 4; Appendix 3 Fig. 5, Appendix 4). 
356 In terms of carbon storage, sediment retention and flood attenuation (relevant to property), which

357 are three of the five ecosystem service categories assessed, on average, approximately $39 \%$ for the

358 North and $63 \%$ for the Outer West region is proposed to remain within areas designated for 359 environmental purposes, compatible with ecosystem service conservation, namely, D’MOSS,

360 Public Open Space or Amenity. The situation with water yield and nutrient retention to dams is

361 more dire with the proposed implementation of the SDP in these two planning regions, leading to

362 about $26 \%$ and $21 \%$ respectively of the hotspot areas remaining within environmental areas in the

363 North and 36\% and 47\% respectively in the Outer West. Sediment retention services are also

364 poorly provided for in the North, with only 33\% falling within an environmental land-use.

365

366

In both regions, the proposed residential land use in the SDPs overlaps with the highest proportions

367

of ecosystem services hotspot areas, with approximately 33\% allocated for combined rural and

368

urban residential uses in the Outer West (Appendix 3) and 38\% combined rural and urban

369

residential uses in the North (Appendix 4). The other proposed land-uses that are not compatible

370 with ecosystem services, namely industry, commercial, office park and mixed use comprise comparably nominal proportions at between $1.3 \%$ and $2.5 \%$ in the North and 0.85 and $1 \%$ in the

372 Outer West.

373

374 The five categories of ecosystem services will be variably affected by the North SDP, with an average of $18 \%$ proposed to fall within agricultural areas, of which $15 \%$ are carbon storage areas, $24 \%$ sediment retention areas, $34 \%$ in water yield ecosystem service areas and $15 \%$ of flood attenuation.

378

\section{Development proposals within ecosystem service hotspots}

380

Approximately 36\% $(\mathrm{n}=658)$ of all EIA applications within Durban between 2009 and 2012 fell within an ecosystem service hotspot, while $84 \%(n=144)$ of sand mining applications were for locations within ecosystem service hotspots (Tables 3 and 4). The ability to store carbon could be impacted as the highest number of EIA and sand mining applications are noted within carbon storage hotspots $(68 \%$ and $86 \%$ of applications respectively of the total applications made within ecosystem service hotspots, i.e. the $36 \%$ ). 
388 With respect to areas providing multiple ecosystem services (Fig. 6), the vast majority of EIAs occurred in areas that only produce one ecosystem service (84\%), with approximately $9 \%$ within areas with two services, $5 \%$ within areas providing three services and $2 \%$ in areas providing four services. Similarly, for sand-mining applications, 93\% of them occurred in areas that only produce one ecosystem service, approximately $4 \%$ within areas with two services, $2 \%$ within areas providing three services and $1 \%$ in areas providing four services.

No EIA or sand mining applications were made in areas with a hotspot richness of five or more services.

\section{Discussion}

\section{Implications of threats to ecosystem services}

401

The findings that the implementation of the SDPs might result in an average transformation or loss 403 of $49 \%$ of ecosystem service hotspots, confirm habitat loss as a threat to the continued supply of ecosystem services within urban areas, and the need for effective municipal planning to reduce this threat (Davids et al. 2016; Daily 2000; Driver 2003). These threats are emphasised by the finding that approximately $36 \%$ of EIA applications and $84 \%$ of sand mining applications made between 2009 and 2012, were located within ecosystem service hotspots.

Our study highlights the importance of the use of ecosystem service hotspots in conservation planning (Egoh et al., 2008; Schröter and Remme, 2016; Schröter et al., 2017; Cimon-Morin et al., 2013) as a potential tool to both avoid foreseeable threats to ecosystem services and human well-

412 being, and to inform conservation and management to ensure the sustainability of ecosystem 413 services (Davids et al., 2016; Schröter et al., 2017). The implications of the findings and options 414 for management of the ecosystem service hotspots considered in this study, are discussed below.

416 The potential loss of carbon storage hotspots, as identified in this study, would be 417 counterproductive to local government strategies to combat climate change. Anthropogenic 
418 changes have already resulted in the planetary boundaries for climate change and biodiversity loss

419 being exceeded (Steffen et al., 2015; Rockstöm et al., 2009). The magnitude of change in supply

420 of ecosystem services that were identified in this study, coupled with the inability of remaining

421 natural areas to meet certain biodiversity targets in Durban (McLean et al., 2016), may push

422 Durban into a state where critical environmental thresholds are crossed, and trigger further non-

423 linear system changes (Steffen et al., 2015; Rockström \& Karlberg, 2010). Although climate

424 change is recognized as a global phenomenon, responses to climate change are being implemented

425 at the local level, raising the importance of local governance in reducing climate-induced risks on

426 communities (Williams et al., 2018; Surminski et al., 2017).

427

428 Over 50\% of disaster-related fatalities are attributed to flood events (Wehn et al., 2015) and a third 429 of economic losses are linked to climate induced risks, with the risk of flooding predicted to 430 increase with global warming (Hirabayashi et al., 2013). The proposed increase in developed 431 'incompatible' land uses will result in increased runoff, and coupled with the potential loss of flood 432 attenuation ecosystem services, may exacerbate flooding impacts with consequences for 433 vulnerable indigent communities, particularly those living in informal settlements in flood prone 434 areas (Arunyawat \& Shrestha, 2016; Im et al., 2009; Du et al., 2012; Williams et al., 2018). This 435 may also result economic costs related to loss or damage to public and private infrastructure.

437 The potential impacts on sediment retention services could result in soil erosion and sedimentation 438 of rivers and dams, threatening water quality and aquatic food sources. In addition, the loss of sediment retention services could lead to blockages of stormwater infrastructure, with resultant economic costs related to the maintenance of the same. About a third of sediment retention services are planned to be replaced by agricultural land uses in both regions. In light of potential impacts associated with agricultural practices including increased runoff and soil erosion and resultant effects on water quality (Arunyawat \& Shrestha, 2016; Kareiva et al., 2007; Baudron \& Giller, 2014), sustainable agricultural practices that limit unwanted impacts on ecosystems and their services to human development are needed (Rockström \& Karlberg, 2010).

447 The substantial amount of nutrient retention hotspots that would be impacted or lost by 
449 and dams and infiltration of nitrogen into groundwater, impacting on aquatic food sources and 450 drinking water and posing a threat to human health (Cirone \& Duncan, 2000). These impacts would 451 also have cost implications for the municipality related to the treatment of water for supply of 452 potable water to residents. In order to mitigate costs and enhance the quality of water supplied, 453 interventions to enhance natural purification of water through wetlands and other habitats and 454 mitigation of water quality degradation due to agriculture and urban development should be 455 considered (Berka et al., 2001; Houlahan \& Findlay, 2004;Verhoeven et al., 2006).

457 The transformation of water yield service areas to agricultural areas and residential and uses will 458 affect water resources. This impact would depend on a range of factors including the types of 459 vegetation before and after transformation (e.g. affecting evapotranspiration rates and moisture 460 transfer rates to soil), whether the change is permanent or temporary and the proposed land use 461 practices related to, for example, irrigation and fertilization applications (Scanlon et al., 2007). 462 Increases in rain-fed cultivation, increases in built-up areas and decreases in forest cover have been 463 shown in increase water yield and decrease water quality (Arunyawat \& Shrestha, 2016; Scanlon 464 et al., 2007). However, increases in surface- or ground-water irrigated agriculture would decrease 465 both water quantity and quality (Scanlon et al., 2007). The condition of natural areas within 466 catchments that supply surface water through runoff must be maintained to ensure yields of high water quality, reduced nutrient loss and reduced soil erosion (Scanlon et al., 2007; Egoh et al 2008).

469

\section{Suggestions for improved planning and management of ecosystem services}

471

472 The inclusion of some ecosystem services into Durban spatial plans such as D’MOSS seems to 473 be partially effective. Some of the reasons include that such planning allocations do not necessarily 474 preclude development, nor do they ensure management of biodiversity in these areas. The 475 challenge remains to efficiently govern ecosystem services in a systematic way. The effective management of ecosystem services would involve the structured incorporation of ecosystem services into decision-making, not only by governments, but also by businesses and individuals and by sectors such as agriculture, forestry, mining and land-use development planning (Pierce et 
480

481

482

483

484

485

486

487

488

489

490

491

492

493

494

495

496

497

498

499

500

501

502

503

504

505

506

507

508

509

510

management of natural land to protect and enhance ecosystem service provision, but also the consideration of the impacts of development objectives on the same.

Davids et al. (2016) identified the need for the consideration of ecosystem service areas within the municipal land-use decision-making frameworks through a possible independent conservation strategy for ecosystem services in Durban. This strategy would include the consideration of the large proportion of ecosystem service provisioning areas, lying outside of protected and managed areas, that are under threat of transformation.

With respect to planning for development within Durban, a proactive approach may be required in order to mitigate the impacts of development proposals within important ecosystem service areas. Observations and expert judgement suggest that the fact that no development applications were made in areas with a hotspot richness of five or more, could be attributed to the potential inaccessibility of these areas in terms of slope or the fact that these are located within drainage lines or rivers. These two factors may thus be considered as natural measures of protection for ecosystem services, except for sand mining activities, that generally target rivers and drainage lines.

The potential loss of important ecosystem service areas needs to be carefully considered prior to the implementation of planning and development proposals in Durban. Practical short-term governance solutions would be to include ecosystem service hotspot areas into D'MOSS where they are currently excluded, to develop guidelines for use of ecosystem service hotspots areas and to develop decision-making guidelines for development applications that fall within ecosystem service priority areas.

\section{Potential for future research}

This research could be expanded in numerous ways. Firstly, the quantification of ecosystem services for various development scenarios would serve as a far more effective tool for planning future development. This could include quantifying the contribution of cultivated areas to ecosystem services provision, which was not assessed in this study. A spatial analysis to quantify 
511 accessibility to areas with high ecosystem service richness (referred to above), could confirm

512 whether natural measures of protection exist for ecosystem service hotspots. The addition of

513 cultural services or non-material NCP, would also provide a more comprehensive understanding

514 of the importance of natural capital for the population of Durban and would provide further

515 motivation for the protection of the same.

516

517 More work is required to assess the compatibility of various land uses to ecosystem service

518 provision (Reyers et al., 2009), including research on the ecological processes linked to ecosystem

519 services and how these are affected by land use change and the social and economic factors that

520 drive changes (Fu et al., 2015). This will provide increased understanding of the links between

521 social, economic and ecological factors that could prove more useful for decision-making.

522

523 Conclusion

524

525 The study highlights that in order to achieve long term sustainability, there is a need to balance the 526 demands of the increasing urbanization in Durban with the demands for human well-being that 527 can be supported by ecosystems services. We highlight the potential societal impacts of strategic 528 and local development threats to the five ecosystem service hotspot areas within city and confirm 529 that management and governance responses are needed. The spatial consideration of threats to 530 ecosystem services is an important tool to assist government to adequately plan for more 531 sustainable cities, whereby development does not unduly impact on natural capital and its ability 532 to provide critical contributions to people.

533

\section{REFERENCES}

535

536

537

538

539

1. Arunyawat, S. \& Shrestha, R., 2016. Assessing Land Use Change and Its Impact on Ecosystem Services in Northern Thailand. Sustainability, 8(8), p.768. Available at: http://www.mdpi.com/2071-1050/8/8/768.

2. Angermeier, P.L., Karr, J.R. 1994. Biological integrity vs. biological diversity as policy directives. BioScience 44, 690-697. 
541

542

543

544

3. Balk, D., McGranahan, G. and Anderson, B. 2008. Urbanization and ecosystems: recent patterns and future implications. Chapter $10 \mathrm{In}$ : The New Global Frontier: Urbanization, Poverty and Environment in the 21st Century, G. Martine, G. McGranahan, M. Montgomery \& R. Fernandez-Castilla (Eds.) Earthscan, pp.183-201.

4. Baró, F., I. Palomo, G. Zulian, P. Vizcaino, D. Haase, E. Gómez-Baggethun, 2016. Mapping ecosystem service capacity, flow and demand for landscape and urban planning: A case study in the Barcelona metropolitan region. Land Use Policy 57, 405-417.

5. Baudron, F. \& Giller, K.E., 2014. Agriculture and nature: Trouble and strife? Biological Conservation, 170 .

6. Blewitt, J., 2015. Understanding sustainable development. Available at: http://medcontent.metapress.com/index/A65RM03P4874243N.pdf\%5Cnhttp://books.goo gle.com/books?hl=en\&lr=\&id=plXXZ5JBIf8C\&oi=fnd\&pg=PR7\&dq=Understanding $+\mathrm{S}$ ustainable + Development\&ots $=$ eBEI2umXSi\&sig=Fm5toyrMT4px3pD6NXAC9oX91Xs \%5Cnhttp://books.google.com/books?hl.

7. Brussard, P.F., Reed, J.M. and Tracy, C.R. 1998. Ecosystem management: what is it really? Landscape and Urban Planning, 40(1-3), pp.9-20.

8. Chan, K.M., Shaw, M.R., Cameron, D.R., Underwood, E.C. \& Daily, G.C., 2006. Conservation planning for ecosystem services. PLoS Biology 4, e379.

9. Cirone, P.A. and Duncan, P.B. 2000. Integrating human health and ecological concerns in health assessments. Journal of Hazardous Materials 782000 1-17.

10. Collier, P. 2008. The bottom billion: Why the poorest countries are failing and what can be done about it. Oxford University Press, Oxford, UK.

11. Convention of Biological Diversity. 2008. COP Decision IX/28. Conference of the Parties, Ninth Meeting, Bonn 19-39 May 2008, 2008(May 2008). Available at: https://www.cbd.int/doc/decisions/cop-09/cop-09-dec-28-en.pdf.

12. Costanza, R., d'Arge, R., de Groot, R., Farber, S., Grasso, M., Hannon, B., Naeem, S., Limburg, K., Paruelo, K., O'Neill, R.V., Raskin, R., Sutton, P., van den Belt, M. 1997. The value of the world's ecosystem services and natural capital. Nature, 387(6630), pp.253260.

13. Daily, G.C. 1999. Developing a scientific basis for managing Earth's life support systems. Conservation Ecology 3(2): 14. 
572

573

574

575

576

577

578

579

580

581

582

583

584

585

586

587

588

589

590

591

592

593

594

595

596

597

598

599

600

601

602

14. Daily, G.C. 2000. Management objectives for the protection of ecosystem services. Environmental Science \& Policy, 3: 333-339.

15. Davenport, N.A., Shackleton, C.M, Gambiza, J. 2012. The direct use value of municipal commonage goods and services to urban households in the Eastern Cape, South Africa. Land Use Policy, 29, pp.548-557.

16. Davids, R., Rouget, M., Boon, R., Roberts, D. 2016. Identifying ecosystem service hotspots for environmental management in Durban, South Africa. Bothalia, 46(2), p.18 pages. Available at: http://www.abcjournal.org/index.php/ABC/article/view/2118.

17. de Groot, R.S., Alkemade R., Braat, L., Heina, L., Willemen, L. 2010. Challenges in Integrating the Concept of Ecosystem services and values in landscape planning, management and decision making. Ecological Complexity, 7(3), pp.260-272. Available at: http://dx.doi.org/10.1016/j.ecocom.2009.10.006.

18. Diaz, S., Pascual, U., Stenseke, M., Martín-López, B., Watson, R.T., Molnár, Z., Hill, R., Chan, K.M.A., Baste, I.A., Brauman, K.A., Polasky, S., Church, A., Lonsdale, M., Larigauderie, A., Leadley, P.W., van Oudenhoven, A.P.E., van der Plaat, F., Schröter, M., Lavorel, S., Aumeeruddy-Thomas, Y., Bukvareva, E., Davies, K., Demissew, S., Erpul, G., Failler, P., Guerra, C.A., Hewitt, C.L., Keune, H., Lindley, S., Shirayama, Y. 2018. Assessing Nature's Contributions to People. Science 359, 270-272.

19. Díaz, S., Demissew, S., $\quad$ Carabias, J., $\quad$ Joly, C., $\quad$ Lonsdale, M., Ash, N., Larigauderie, A., Adhikari, J.R, Arico, S., Baldi, A., Bartuska, A. Baste, I.A., Bilgin, A., Brondizio, E., Chan, K.M.A, Figueroa, V.E., Duraiappah, A. Fischer, M., Hill, R., Koetz, T., Leadley, P., Lyver, L., Mace, G.M., Martin-Lopez, B., Okumura, M., Pacheco, D., Pascual, U., Pe'rez, E.S., Reyers, B., Roth, E., Saito, O., Scholes, R.J., Sharma, N., Tallis, H., Thaman, R., Watson, R., Yahara, T., Hamid, Z.A., Akosim, C., Al-Hafedh, Y., Allahverdiyev, R., Amankwah, E., Asah, S.T., Asfaw, Z., Bartus, G., Brooks, L.A., Caillaux, J., Dalle, E., Darnaedi, D., Driver, A., Erpul, G., Escobar-Eyzaguirre, P., Failler, P., Fouda, A.M.M., Fu, B., Gundimeda, H., Hashimoto, S., Homer, F., Lavore, S., Lichtenstein, G., Mala, W.A., Mandivenyi, W., Matczak, P., Mbizvo, C., Mehrdadi, M., Metzger, J.P., Mikissa, J.B., Moller, H., Mooney, H.A., Mumby, P., Nagendra, H., Nesshover, C., Oteng-Yeboah, A.P., György, P., Roue', M., Rubis, J., 78, Schultz, M., Smith, P., Sumaila, R., Takeuchi, K., Thomas, S., Verma, M., Yeo-Chang, Y., Zlatanova, 
603 D. 2015. The IPBES Conceptual Framework - connecting nature and people. Current 604 Opinion in Environmental Sustainability, 14, pp.1-16.

605 20. Di'az, S., Tilman, D., Fargione, J., Chapin, F.S. III, Dirzo, R., Ktzberber, T. 2005. 606 Biodiversity regulation of ecosystem services. In: Trends and Conditions (ed. MA). Island 607 Press, Washington, DC, pp. 279-329.

608 21. Driver, A., Cowling, R.M. and Maze, K. 2003. Planning for Living Landscapes: 609 Perspectives and Lessons from South Africa. Washington, DC: Center for Applied Biodiversity Science at Conservation International; Cape Town: Botanical Society of South Africa. ISBN 1-874999-29-5.

22. Du, J.; Qian, L.; Rui, H.; Zuo, T.; Zheng, D.; Xu, Y.; Xu, C.-Y. Assessing the effects of urbanization on annual runoff and flood events using an integrated hydrological modelling system for Qinhuai River basin, China. J. Hydrol. 2012, 464-465, 127-139.

23. Egoh, B., Reyers, B., Rouget, M., Bode, M. \& Richardson, D.M., 2009. Spatial congruence between biodiversity and ecosystem services in South Africa. Biological Conservation 142, 553-562. http://dx.doi.org/10.1016/j.biocon.2008. 11.009.

24. Ehrlich P.R., and Wilson E.O. 1991. Biodiversity studies: Science and policy. Science 253: 758-762.

25. eThekwini Municipality. 2012. Integrated Development Plan. 5 Year Plan. 2012/20132016/2017.

[Online]

URL:

623 http://www.durban.gov.za/City_Government/City_Vision/IDP/Documents/eThekwini\%2 0IDP\%202013_14.pdf

26. eThekwini Municipality. 2012a. State of biodiversity report 2011/2012, Department of Environmental Planning and Climate Protection, Durban, viewed 10 June 2013, from http://www.durban.gov.za/City_Services/development_planning management/environmental_planning_climate_protection/Publications/ Documents/State_of_Biodiversity_Report_2011_2012.pdf

27. Fu, B., Zhang, L., Xu, Z., Zhao, Y., Wei, Y., Skinner, D. 2015. Ecosystem services in changing land use. Journal of Soils and Sediments, 15(4), pp.833-843. Available at: tps://doi.org/10.1007/s11368-015-1082-x. InVEST and GIS analysis. Unpublished document, Department of Environmental Planning 
634

635

636

637

638

639

640

641

642

643

644

645

646

647

648

649

650

651

652

653

654

655

656

657

658

659

660

661

662

663

and Climate Protection, eThekwini Municipality, Durban.

29. Golder Associates Africa. 2010. EThekwini Municipality Integrated Assessment Tool for Climate Change”, Prepared for the eThekwini Municipality, Report Number 10290-974313, Durban.

30. Holden, S.T. \& Otsuka, K. 2014. The roles of land tenure reforms and land markets in the context of population growth and land use intensification in Africa. Food Policy, 48, pp.8897. Available at: http://dx.doi.org/10.1016/j.foodpol.2014.03.005.

28. Hirabayashi, Y., Mahendran, R., Koirala, S., Konoshima, L., Yamazaki, D., Watanabe, S., Kim, H., Kanae, S. 2013. Global flood risk under climate change. Nat. Clim. Chang. 3, $816-821$

29. Houlahan, J. E. and Findlay, C. S. 2004. Estimating the "critical" distance at which adjacent land-use degrades wetland water and sediment quality. Landscape Ecology 19: $677-690$.

30. Im, S.; Kim, H.; Kim, C.; Jang, C. Assessing the impacts of land use changes on watershed hydrology using MIKE SHE. Environ. Geol. 2009, 57, 231-239.

31. Kareiva, P., Watts, S., McDonald, R., Boucher, T., 2007. Domesticated nature: shaping landscapes and ecosystems for human welfare. Science 316, 1866-1869.

32. Karr, J.R. 1991. Biological integrity: a long-neglected aspect of water resource management. Ecol. Appl. 1, 66-84.

33. Larigauderie, A., Prieur-Richard, AH; Mace, G., Lonsdale, M., Mooney, H.A., Brussaard, L., Cooper, D., Cramer, W., Daszak, P., Díaz, S., Duraiappah, A., Elmqvist, T., Faith, D.O., Jackson, L.E., Krug, C., Leadley, P.W., Le Prestre, P., ; Matsuda, H., Yahara, T. 2012. Biodiversity and ecosystem services science for a sustainable planet: The DIVERSITAS vision for 2012-20. Curr. Opin. Environ. Sust. 4, 101-105.

34. McGranahan, G., Marcotullio, P., Bai, X., Balk, D., Braga, T., Douglas, I., Elmqvist, T., Rees, W., Satterthwaite, D., Songsore, J., Zlotnik, H. 2005, 'Ecosystems and human wellbeing', Vol. 1, in Current state and trends, Chapter 27, Urban Systems. Island Press, Washington, DC. ISBN 1-55963-227.

35. McLean, C.T., Ground, L.E., Boon, R.G.C., Roberts, D.C., Govender, N. \& McInnes, A., 2016. Durban’ s Systematic Conservation Assessment. 
664

665

666

667

668

669

670

671

672

673

674

675

676

677

678

679

680

681

682

683

684

685

686

687

688

689

690

691

692

693

694

36. Millenium Ecosystem Assessment (MEA). 2005. Ecosystems and Human Well-Being: synthesis report. Island Press, Washington D.C.

37. Mittermeier RA, Robles Gil P, Hoffmann M, Pilgrim J, Brooks T, Mittermeier CG, Lamoreux J, da Fonseca GAB (2004) Hotspots revisited: Earthd:

38. Parmesan, C., Yohe, G. 2003. A globally coherent fingerprint of climate change impacts across natural ecosystems. Nature, 421 (2003), pp. 37-42

39. Pierce, S. M. Cowling, R.M, Knight A.T., Lombard A.T., Rouget, M. and Wolf, T. 2005. Systematic conservation planning products for land-use planning: Interpretation for implementation. Biological Conservation 125: 441-458.

40. Potschin, M.B. \& Haines-Young, R.H., 2011. Ecosystem services: Exploring a geographical perspective. Progress in Physical Geography, 35(5), pp.575-594. Available at: http://ppg.sagepub.com/cgi/doi/10.1177/0309133311423172.

41. Press, W.H., Flannery, B.P., Teukolsky, S.A. \& Vetterling, W.T., 1992. Numerical recipes in FORTRAN: The art of scientific computing, 2nd edn., Cambridge University Press, Cambridge, England, p. 694.

42. Primmer, E., Jokinen, P., Blicharska, M., Barton, D.N., Bugter, R., Potschin, M. 2015. Governance of Ecosystem Services: A framework for empirical analysis. Ecosystem Services, 16, pp.158-166. Available at: http://dx.doi.org/10.1016/j.ecoser.2015.05.002.

43. Reyers, B., O’Farrell, P., Cowling, R.M., Egoh, B.N., Le MAitre, D.C., Vlok, H.J. 2009. Ecosystem services, land-cover change, and stakeholders: Finding a sustainable foothold for a semiarid biodiversity hotspot. Ecology and Society, 14(1). Available at: https://www.ecologyandsociety.org/vol14/iss1/art38/

44. Roberts, D. \& Donoghue, S.O., 2013. Urban environmental challenges and climate change action in Durban, South Africa. Environment \& Urbanization, 25(2), pp.299-319.

45. Rockström, J. \& Karlberg, L., 2010. The quadruple squeeze: Defining the safe operating space for freshwater use to achieve a triply green revolution in the anthropocene. Ambio, 39(3), pp.257-265.

46. Rockström, J. and Sukhdev P. 2017. How food connects all the SDGs. Stockholm Resilience Center, http:/www.stockholmresilience.org/research/research-news/2016-0614-how-food-connects-all-the-sdgs.html, accessed in Jun 2017.

47. Rockström, J., Steffen, W., Noone, K., Persson, A., Chapin, F.S., Lam- bin, E.F. 2009. A 
695

696

697

698

699

700

701

702

703

704

705

706

707

708

709

710

711

712

713

714

715

716

717

718

719

720

721

722

723

724

725

safe operating space for humanity. Nature, 461, 472-475.

48. Schröter, M., R.P. Remme, 2016. Spatial prioritisation for conserving ecosystem services: comparing hotspots with heuristic optimisation. Landsc. Ecol. 31, 431-450.

49. Schröter, M., R. Kraemer, S. Ceauşu, G.M. Rusch, 2017. Incorporating threat in hotspots and coldspots of biodiversity and ecosystem services. Ambio 46, 756-768

50. Seto, K.C., Güneralp, B. \& Hutyra, L.R. 2012. Global forecasts of urban expansion to 2030 and direct impacts on biodiversity and carbon pools. Proceedings of the National Academy of Sciences of the United States of America, 109(40), pp.16083-8. Available at: http://www.ncbi.nlm.nih.gov/pubmed/22988086 [Accessed March 6, 2017].

51. Shackleton, C.M., Shackleton, S.E. 2004. The importance of non-timber forest products in rural livelihood security and as safety nets: A review of evidence from South Africa. South African Journal of Science, 100, pp. 658-664.

52. Singh, S.P., 2002. Balancing the approaches of environmental conservation by considering ecosystem services as well as biodiversity. Current Science 82(11), 1331-1335.

53. Stoian, D., 2005. Making the best of two worlds: Rural and peri-urban livelihood options sustained by nontimber forest products from the Bolivian Amazon. World Development, 33(9 SPEC. ISS.), pp.1473-1490.

54. Surminski, S., Aerts, J., Alexander, D., Di Bucci, D., Mechler, R., Mysiak, J., Wilkinson, E. 2017. Prevention and mitigation: Avoiding and reducing the new and existing risks. In Science for Disaster Risk Management 2017: Knowing Better and Losing Less; Poljanšek, K., Marín Ferrer, M., De Groeve, T., Clark, I., Eds.; Publications Office of the European Union: Luxembourg; pp. 444-502.

55. Sutherland, C., Hordijk, M., Lewis, B., Meyer, C. \& Buthelezi, B., 2014, Water and sanitation delivery in eThekwini Municipality: A spatially differentiated approach, Environment \& Urbanisation 26(2), 469-488. http://dx.doi.org/10.1177/ 0956247814544871

56. Tallis, H., \& Polasky, S. (2009). Mapping and valuing ecosystem services as an approach for conservation and natural-resource management. Annals of the New York Academy of Sciences, 1162(1), 265-283.

57. TEEB - The Economics of Ecosystems and Biodiversity. 2011. TEEB Manual for Cities: Ecosystem Services in Urban Management. www.teebweb.org 
726

727

728

729

730

731

732

733

734

735

736

737

738

739

740

741

742

743

744

745

746

747

748
58. TEEB. 2010. The Economics of Ecosystems and Biodiversity: Mainstreaming the Economics of Nature: A synthesis of the approach, conclusions and recommendations of TEEB.

59. Turner, W.R., Brandon, K., Brooks, T.M., Costanza, R., Da Fonseca, G.A.B. \& Portela, R., 2007. Global conservation of biodiversity and ecosystem services. BioScience 57(10), 868-873. http://dx.doi.org/10.1641/B571009.

60. United Nations Development Programme. 2016. UNDP Support to the implementation of the 2030 agenda for sustainable development. , (January), p.9.

61. United Nations, 2015. "Transforming our world: The 2030 agenda for sustainable development." New York: United Nations, Department of Economic and Social Affairs.

62. United Nations, Department of Economic and Social Affairs (UN DESA), Population Division. 2015. World population prospects: The 2015 revision, New York.

63. United Nations. 2015. Resolution Adopted by the General Assembly on 25 Septermber 2015. 42809(September), pp.1-35. Available at: http://www.un.org/ga/search/view_doc.asp?symbol=A/RES/70/1\&Lang=E.

64. Verhoeven, J.T.A., Arheimer, B., Yin, C. and Hefting, M.M. 2006. Regional and global concerns over wetlands and water quality. TRENDS in Ecology and Evolution 21, 96-103

65. Wehn, U.. Rusca, M., Evers, J.; Lanfranchi, V. 2015. Participation in flood risk management and the potential of citizen observatories: A governance analysis. Environ. Sci. Policy, 48, 225-236 


\section{Table 1 (on next page)}

Ecosystem functions and their contribution to the services (Glenday, 2012) 
1 Table 1: Ecosystem services (modified from Glenday, 2012)

Five Ecosystem Service Sub-set of Ecosystem Service Categories

Categories

\begin{tabular}{|c|c|}
\hline Carbon storage & 1. Mitigating global climate change \\
\hline Water yield & 2. Providing water supply to dams \\
\hline \multirow[t]{4}{*}{ Sediment retention } & 3. Reducing need for harbour dredging \\
\hline & 4. Reducing loss of dam capacity to sedimentation \\
\hline & 5. Reducing sewer pipe maintenance due to sedimentation \\
\hline & 6. Reducing stormwater pipe and culvert maintenance due to sedimentation \\
\hline \multirow[t]{3}{*}{$\begin{array}{lr}\text { Nutrient } & \text { retention } \\
\text { (nitrogen } & \text { and } \\
\text { phosphorus in runoff) }\end{array}$} & $\begin{array}{l}\text { 7. Nitrogen retention for improving water quality in dams (reducing harmful algal } \\
\text { blooms, filtration needed for domestic water supplies, alien water plant proliferation, } \\
\text { and dam system maintenance) }\end{array}$ \\
\hline & 8. Phosphorus retention for improving water quality in dams \\
\hline & $\begin{array}{l}\text { 9. Nitrogen retention for improving water quality in estuaries for fisheries and recreation } \\
\text { 10. Phosphorus retention for improving water quality in estuaries for fisheries and } \\
\text { recreation }\end{array}$ \\
\hline \multirow[t]{3}{*}{ Flood attenuation } & $\begin{array}{l}\text { 11. Reducing negative flood impacts on populations living in floodplain areas (loss of } \\
\text { life, loss of quality of life) }\end{array}$ \\
\hline & 12. Reducing flood damage to private property \\
\hline & 13. Reducing flood damage to public infrastructure \\
\hline
\end{tabular}

2 


\section{Table 2 (on next page)}

Ecosystem service Strategic Development Plan analyses combinations and summary 
2 Table 2: Ecosystem service - Strategic Development Plan analyses combinations and summary of key findings

\begin{tabular}{|c|c|c|}
\hline & \multicolumn{2}{|c|}{ Strategic Development Plans (two selected planning regions) } \\
\hline & North Region & Outer West Region \\
\hline $\begin{array}{l}\text { Allocation of future } \\
\text { land uses to the } 13 \\
\text { Individual ecosystem } \\
\text { services areas }\end{array}$ & $\begin{array}{l}\text { - } 54 \% \text { of all ES areas in environmental land } \\
\text { use: carbon storage }(62 \%) \text {, flood } \\
\text { attenuation public and private } \\
\text { infrastructure }(61 \% \text { each) and phosphorus } \\
\text { retention dams and estuaries ( } 75 \% \text { each) } \\
-40 \% \text { of urban residential in sediment } \\
\text { retention storm drains and sewer pipes } \\
\text { and } 38 \% \text { urban residential in nitrogen } \\
\text { retention estuaries } \\
-26 \% \text { agriculture to fall within water yield, } \\
30 \% \text { in sediment retention dams and } 32 \% \\
\text { in nitrogen retention dams }\end{array}$ & $\begin{array}{l}\text { - } 62 \% \text { of all ES areas in environmental land use: } \\
\text { carbon storage }(82 \%) \text {, flood attenuation public } \\
\text { and private infrastructure ( } 77 \% \text { each), sediment } \\
\text { retention harbor }(74 \%) \\
-51 \% \text { of water yield, } 47 \% \text { of nitrogen retention } \\
\text { dams and } 42 \% \text { nitrogen retention estuaries in } \\
\text { rural residential \& tourism } \\
-33 \% \text { of phosphorus retention estuaries in urban } \\
\text { residential }\end{array}$ \\
\hline $\begin{array}{l}\text { Allocation of future } \\
\text { land use to the } 5 \\
\text { ecosystem service } \\
\text { categories (carbon } \\
\text { storage, water yield, } \\
\text { sediment retention, } \\
\text { nutrient retention \& } \\
\text { flood attenuation) }\end{array}$ & $\begin{array}{l}-60 \% \text { at risk of transformation } \\
-\quad 38 \% \text { of all ES areas in urban and rural } \\
\text { residential land use: carbon storage } \\
(21 \%) \text {, water yield }(34 \%) \text {, sediment } \\
\text { retention }(36 \%) \text {, nutrient retention }(71 \%) \text {, } \\
\text { flood attenuation }(27 \%) \\
-\quad 18 \% \text { of all ES areas in agricultural land } \\
\text { use: carbon storage }(15 \%) \text {, water yield } \\
(34 \%) \text {, sediment retention }(24 \%) \text {, flood } \\
\text { attenuation }(15 \%) \\
-39 \% \text { of all ES areas in environmental land } \\
\text { use } \\
-\% \text { ES functions in environmental land- } \\
\text { uses: carbon storage }(60 \%) \text {, water yield } \\
\text { (26\%), sediment retention }(33 \%) \text {, nutrient } \\
\text { retention dams }(21 \%) \text {, flood attenuation } \\
\text { (54\%) }\end{array}$ & $\begin{aligned} &- 47 \% \text { at risk of transformation } \\
&- 33 \% \text { of all ES areas in urban and rural residential } \\
& \text { land uses: carbon storage }(10 \%) \text {, water yield } \\
&(53 \%) \text {, sediment retention }(34 \%) \text {, nutrient } \\
& \text { retention }(51 \%) \text {, flood attenuation }(17 \%) \\
&-2 \% \text { of all ES areas in agricultural land use } \\
&-63 \% \text { of all ES areas in environmental land uses: } \\
& \text { carbon storage }(86 \%) \text {, water yield }(36 \%) \text {, } \\
& \text { sediment retention }(62 \%) \text {, nutrient retention } \\
&(47 \%) \text {, flood attenuation }(82 \%)\end{aligned}$ \\
\hline
\end{tabular}

3 


\section{Table 3(on next page)}

Ecosystem service Strategic Development Plan analyses combinations and summary 
1 Table 3: Ecosystem service - Strategic Development Plan analyses combinations and summary of key 2 findings

\begin{tabular}{|c|c|c|}
\hline & \multicolumn{2}{|c|}{ Development Proposals (entire eThekwini Municipal Area) } \\
\hline & Environmental Impact Assessment (EIA) sites & Sand mining sites \\
\hline $\begin{array}{l}13 \text { Individual } \\
\text { ecosystem services } \\
\text { and their allocation } \\
\text { to future land use }\end{array}$ & $\begin{array}{l}\text { - } 36 \% \text { of all EIAs in ecosystem service hotspots } \\
\text { - } \quad \text { Of all EIAs in hotspots: } 68 \% \text { made in carbon } \\
\text { storage hotspots, } 8 \% \text { in sediment retention } \\
\text { hotspots, } 7 \% \text { in water yield hotspots }\end{array}$ & $\begin{array}{l}-84 \% \text { of sand mining proposals in } \\
\text { ecosystem service hotspots } \\
\text { - Of all sand mining applications in hotspots: } \\
86 \% \text { in carbon storage hotspots and } 7 \% \text { in } \\
\text { water yield hotspots }\end{array}$ \\
\hline $\begin{array}{lr}\text { Ecosystem } & \text { service } \\
\text { hotspot richness } & \text { rive } \\
\text { relative } & \text { to } \\
\text { proposed } & \\
\text { development sites }\end{array}$ & $\begin{array}{l}-\quad 84 \% \text { in areas providing only one service } \\
-\quad 9 \% \text { in areas providing two services } \\
-\quad 5 \% \text { within areas providing three services } \\
-\quad 2 \% \text { in areas providing four services } \\
-\quad \text { No application in hotspot richness of } 5 \text { or } \\
\text { more }\end{array}$ & $\begin{array}{l}\text { - } \quad 93 \% \text { in areas providing one service } \\
-\quad 4 \% \text { within areas with two services, } \\
-\quad 2 \% \text { within areas providing three services } \\
\text { and } \\
-\quad 1 \% \text { in areas providing four services. } \\
-\quad \begin{array}{l}\text { No application in hotspot richness of } 5 \text { or } \\
\text { more }\end{array}\end{array}$ \\
\hline
\end{tabular}

3 


\section{Table 4(on next page)}

EIA and Sand Mining within Ecosystem Service Hotspots 
1

2 Table 4: EIA and Sand Mining Applications within Ecosystem Service Hotspots

\begin{tabular}{|c|c|c|c|c|}
\hline & No. of EIAs & $\begin{array}{l}\% \text { EIAs in } \\
\text { ES area }\end{array}$ & $\begin{array}{l}\text { No. of Sand- } \\
\text { mining } \\
\text { applications }\end{array}$ & $\begin{array}{c}\text { \% Sand- } \\
\text { mining in } \\
\text { ES area }\end{array}$ \\
\hline \multicolumn{5}{|l|}{ 1. Durban } \\
\hline Totals & 658 & 36.3 & 144 & 84.0 \\
\hline \multicolumn{5}{|l|}{ 2. Ecosystem services areas } \\
\hline Carbon & 164 & 68.6 & 105 & 86.8 \\
\hline Water yield & 17 & 7.1 & 8 & 6.6 \\
\hline Flood attenuation Pop & 3 & 1.3 & - & - \\
\hline $\begin{array}{l}\text { Flood attenuation public } \\
\text { infrastructure }\end{array}$ & 2 & 0.8 & 1 & 0.8 \\
\hline $\begin{array}{l}\text { Flood attenuation private } \\
\text { infrastructure }\end{array}$ & 5 & 2.1 & 1 & 0.8 \\
\hline Sediment retention - dams & 5 & 2.1 & 3 & 2.5 \\
\hline $\begin{array}{l}\text { Sediment retention - sewer } \\
\text { pipes }\end{array}$ & 19 & 7.9 & 2 & 1.7 \\
\hline $\begin{array}{l}\text { Sediment retention - storm } \\
\text { drains }\end{array}$ & 16 & 6.7 & 1 & 0.8 \\
\hline Sediment retention harbour & 7 & 2.9 & - & - \\
\hline Nitrogen retention - dams & - & - & - & - \\
\hline Nitrogen retention - estuaries & - & - & - & - \\
\hline Phosphorus retention - dams & - & - & - & - \\
\hline $\begin{array}{l}\text { Phosphorus retention - } \\
\text { estuaries }\end{array}$ & 1 & 0.4 & - & - \\
\hline Total & 239 & 100 & 121 & 100 \\
\hline
\end{tabular}

3

4 
Figure 1

Hotspots for 13 ecosystem services in the eThekwini Municipal Area (from (Davids et al. 2016)

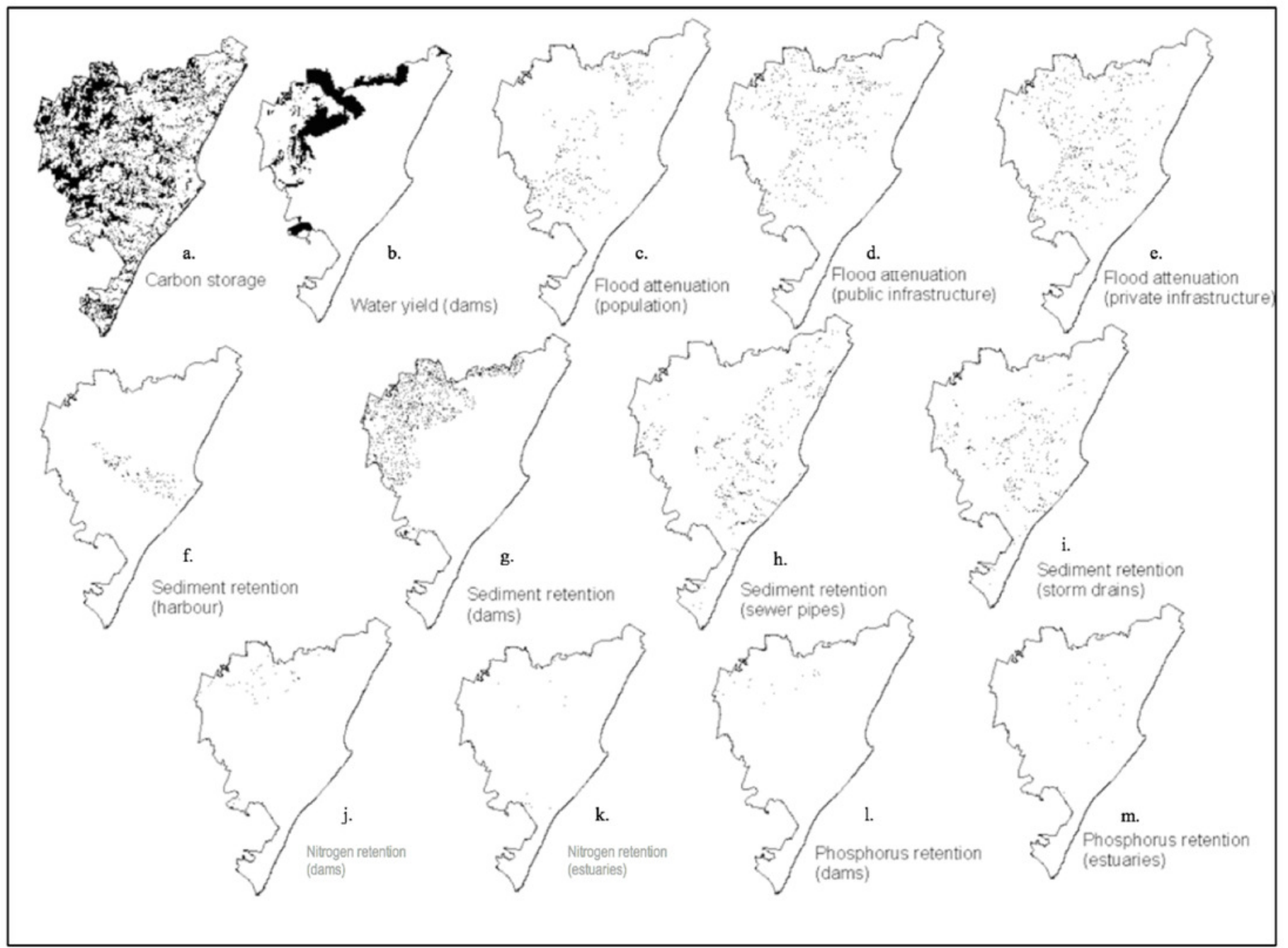


Figure 2

Ecosystem service hotspot richness map 


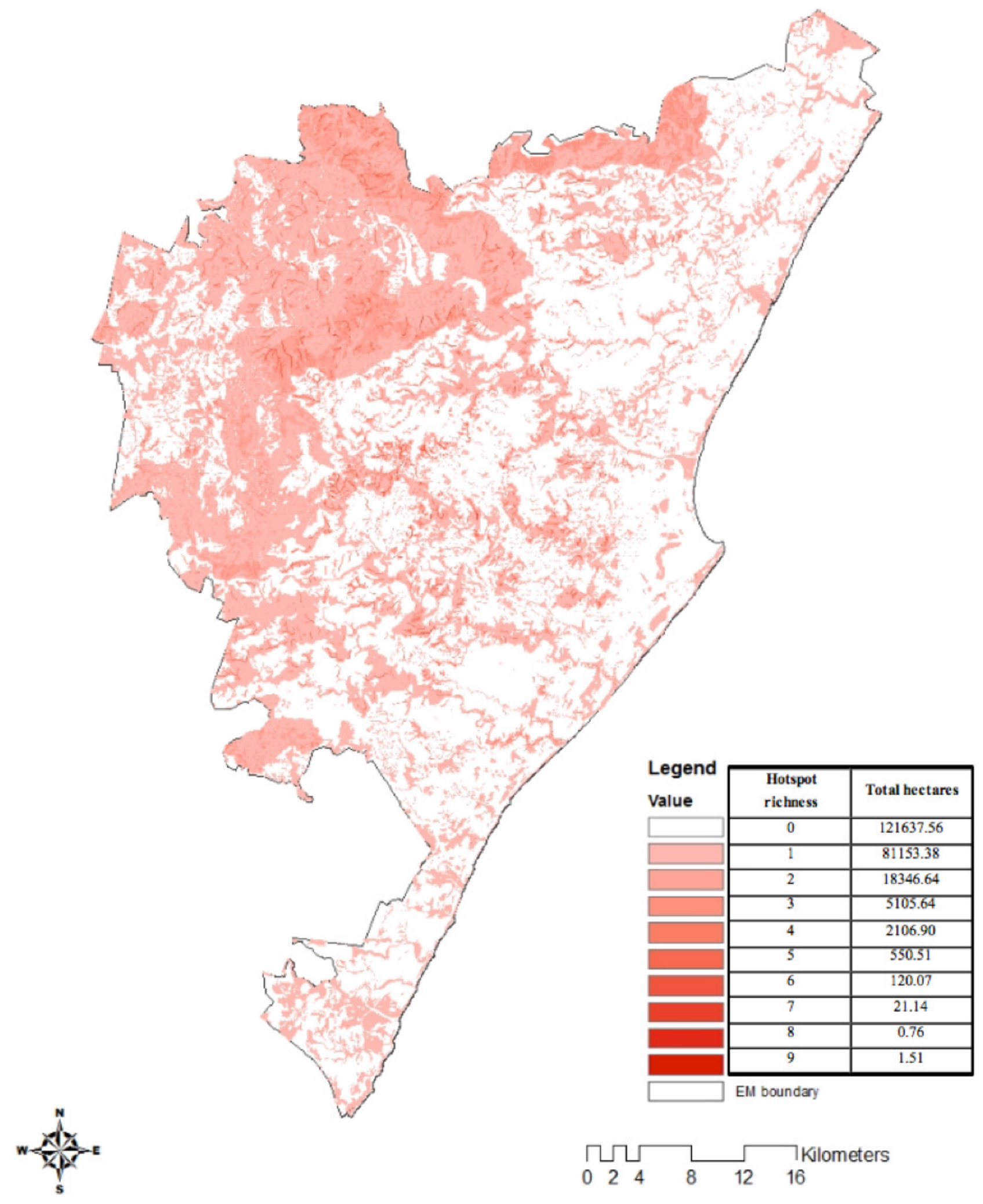


Figure 3

eThekwini Municipality Spatial Planning Regions and areas within these covered by town planning schemes 


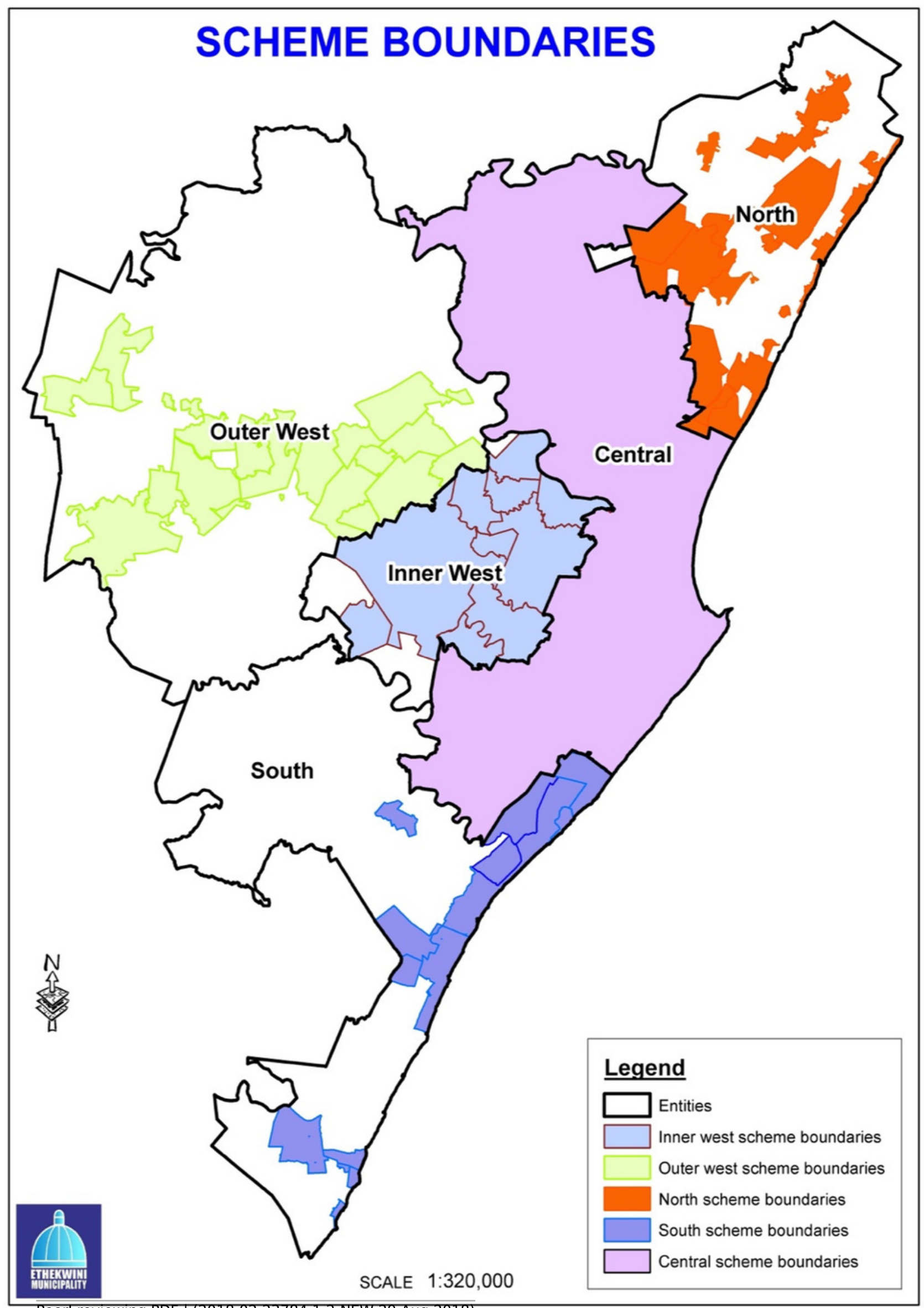




\section{Figure 4}

Proportions of proposed land use relative to ecosystem function hotspots in the Northern Planning Region (\%)

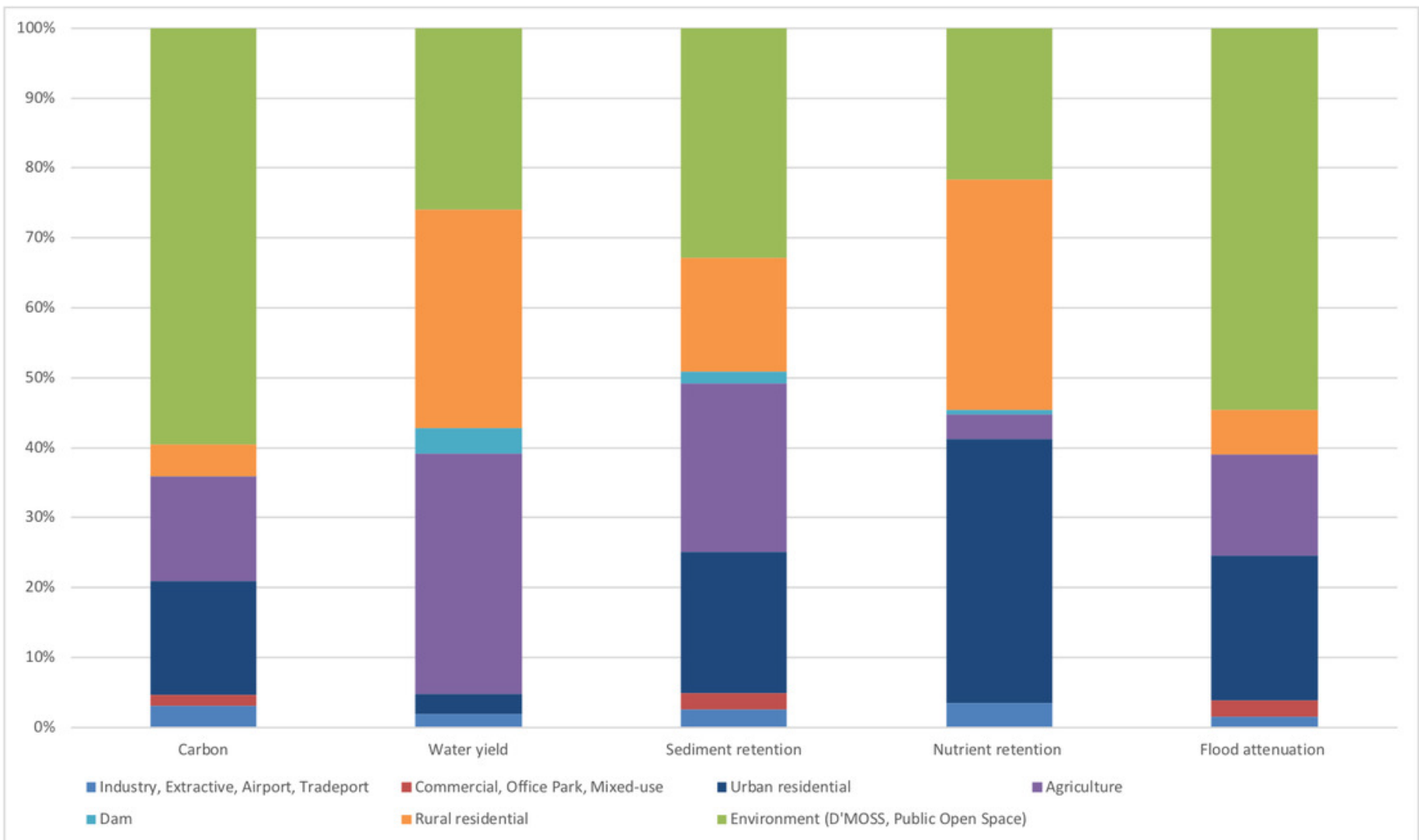




\section{Figure 5}

Proportions of proposed land use relative to ecosystem function hotspots in the Outer West Planning Region (\%)

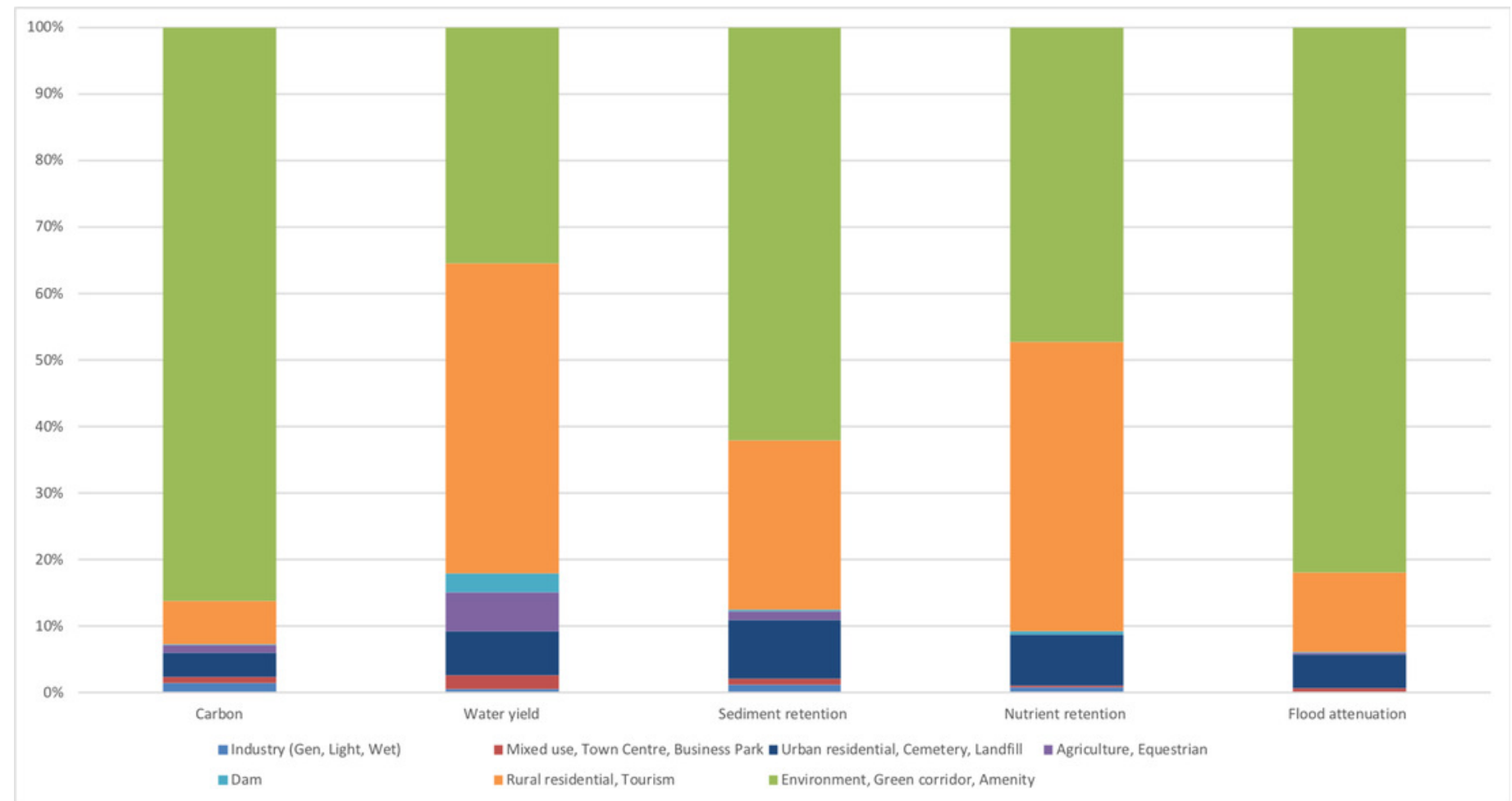


Figure 6

Development and sand mining applications relative to hotspot richness 


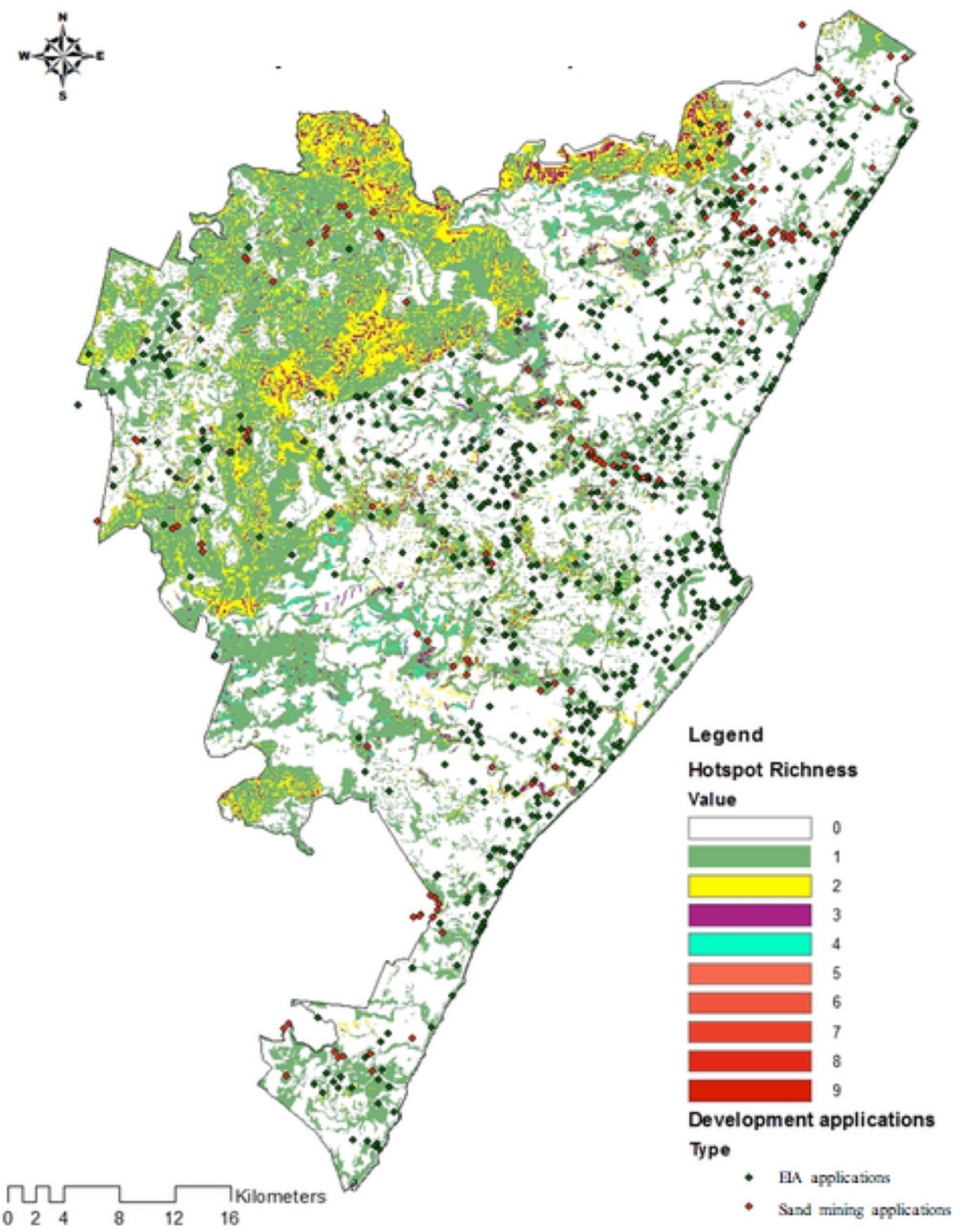

